\title{
Antioxidant Activities of Black Soybean Extract (Glycine max (L.) Merr.) and Daidzein as Hydroxyl and Nitric Oxide Scavengers
}

\author{
Mulia Irwan, ${ }^{1}$ Ermi Girsang, ${ }^{1}$ Ali Napiah Nasution, ${ }^{1}$ I Nyoman Ehrich Lister, ${ }^{1}$ Annisa Amalia, ${ }^{2}$ \\ Wahyu Widowati ${ }^{3}$ \\ ${ }^{1}$ Faculty of Medicine, Universitas Prima Indonesia, Medan, Indonesia, \\ ${ }^{2}$ Aretha Medika Utama, Biomolecular and Biomedical Research Center, West Java, Indonesia, \\ ${ }^{3}$ Faculty of Medicine Maranatha Christian University, Bandung, Indonesia
}

\begin{abstract}
Free radicals are known as a leading factor in aging. Nitric oxide (NO) and $\mathrm{O}_{2}{ }^{\bullet}$ - have been shown to inhibit the synthesis of matrix components and stimulate prolidase activities involved in collagen degradation. Hydroxyl $\left({ }^{\circ} \mathrm{OH}\right)$ radical is a precursor of hyaluronic acid degradation. Antioxidants act as a scavenger for free radicals, creating a possibility to use them to prevent the aging process. Black soybeans (Glycine max (L.) Merr.) contain bioactive compounds that have the ability to scavenge free radicals, including daidzein. Daidzein belongs to the isoflavones group which is the most active compound in black soybean. This study aimed to understand the antioxidant activities of the black soybean extract (BSE) and daidzein compound in the scavenging of ${ }^{\circ} \mathrm{OH}$ and $\mathrm{NO}$ radicals and was performed at the Aretha Medika Utama-Biomolecular and Biomedical Research Center (BBRC), Bandung, Indonesia, from September to November 2018. The scavenging activity of ${ }^{\circ} \mathrm{OH}$ was assessed using the deoxyribose method, while the assessment of the scavenging of NO radicals was carried out using the sodium nitroprusside method. BSE and daidzein had an ${ }^{\circ} \mathrm{OH}$ scavenging activity with an IC50 value of $71.07 \mu \mathrm{g} / \mathrm{mL}$, followed by daidzein with $24.57 \mu \mathrm{g} / \mathrm{mL}$. A higher NO scavenging activity was seen in BSE with an IC50 of 71.60 $\mu \mathrm{g} / \mathrm{mL}$ followed by daidzein with $35.68 \mu \mathrm{g} / \mathrm{mL}$. Daidzein has a higher antioxidant activity through hydroxyl and nitric oxide scavenging compared to Glycine max (L.) Merr. extract. Hence, daidzein has a higher potential as an anti-aging agent based on the free-radical theory of aging.
\end{abstract}

Key words: Antioxidants, black soybean, free radicals, hydroxyl radical, nitric oxide

\section{Aktivitas Antioksidan Ekstrak Kedelai Hitam (Glycine max (L.) Merr.) dan Daidzein sebagai Pemerangkap Hidroksil dan Nitrogen Monoksida}

\begin{abstract}
Abstrak
Radikal bebas dikenal sebagai faktor utama penuaan. Nitrogen monoksida (NO) dan $\mathrm{O}_{2}$ - -telah terbukti menghambat sintesis komponen matriks dan merangsang aktivitas prolidase yang terlibat dalam degradasi kolagen. Radikal hidroksil $\left({ }^{\circ} \mathrm{OH}\right)$ adalah prekursor dari degradasi asam hialuronat. Antioksidan bertindak sebagai pemerangkap radikal bebas sehingga dapat digunakan untuk mencegah proses penuaan. Kedelai hitam (Glycine max (L.) Merr.) mengandung senyawa bioaktif yang mampu memerangkap radikal bebas, salah satunya adalah daidzein. Daidzein termasuk dalam kelompok isoflavon yang merupakan senyawa paling aktif dalam kedelai hitam. Penelitian ini bertujuan untuk mengetahui aktivitas antioksidan, pemerangkapan ${ }^{\circ} \mathrm{OH}$ dan $\mathrm{NO}$ dari ekstrak etanol kedelai hitam (BSE) dan senyawa daidzein. Penelitian ini dilakukan selama bulan September sampai dengan November tahun 2018 di Laboratorium Aretha Medika Utama Biomolecular and Biomedical Research Center (BBRC) Bandung. Pemerangkapan ${ }^{\circ} \mathrm{OH}$ dilakukan dengan metode deoksiribosa, sedangkan pemerangkapan radikal NO dilakukan dengan metode menghitung natrium nitroprusida. BSE dan daidzein memiliki aktivitas pemerangkapan ${ }^{\circ} \mathrm{OH}$ dengan nilai IC50 71,07 $\mu \mathrm{g} / \mathrm{mL}$ diikuti oleh daidzein 24,57 $\mu \mathrm{g} / \mathrm{mL}$. Aktivitas pemerangkapan NO pada BSE ditunjukkan dengan IC50 71,60 $\mu \mathrm{g} / \mathrm{mL}$ sementara daidzein 35,68 $\mathrm{gg} / \mathrm{mL}$. Daidzein memiliki aktivitas antioksidan yang lebih tinggi berdasarkan pemerangkapan ${ }^{\circ} \mathrm{OH}$ dan NO dibanding BSE. Oleh karena itu, daidzein memiliki potensi lebih sebagai antiaging menurut teori penuaan akibat radikal bebas.
\end{abstract}

Kata kunci: Antioksidan, daidzein, Glycine max (L.) Merr., hidroksil, nitrogen monoksida

Corresponding Author: Ermi Girsang, Faculty of Medicine Universitas Prima Indonesia, Medan, Jalan Belanga No. 1 Simp. Ayahanda, Medan, North Sumatera 20118, Indonesia, Email: ermigirsang@unprimdn.ac.id 


\section{Introduction}

Free radicals are classified into two groups termed as Reactive Oxygen Species (ROS) and Reactive Nitrogen Species (RNS). The examples for ROS include hydrogen peroxide $\left(\mathrm{H}_{2} \mathrm{O}_{2}\right)$, superoxide anion $\left(\mathrm{O}_{2}^{-}\right)$, hydroxyl radical $\left(\cdot{ }^{\circ} \mathrm{OH}\right)$, peroxyl radical $\left(\cdot \mathrm{OH}_{2}\right)$, and peroxynitrous acid $\left(\mathrm{HNO}_{3}\right)$ while the examples for RNS are nitric oxide (NO), nitrous oxide $\left(\mathrm{N}_{2} \mathrm{O}\right)$, peroxynitrite $\left(\mathrm{NO}_{3}^{-}\right)$, and nitroxyl anion (HNO). ${ }^{1}$

Moreover, the free radical theoryofagingstated that free radicals are the leading factor of aging. ${ }^{2}$ It has been reported that an excessive number of free radicals such as ${ }^{\circ} \mathrm{OH}$ and $\mathrm{NO}$ degrades some aging-related proteins. As a matter of fact, NO stimulates prolidase activities involved in the terminal step of collagen degradation. ${ }^{3}$ Collagen constitutes approximately $70-80 \%$ of the total skin weight in the human body. Loss of collagen reduces the skin tensile strength. ${ }^{4,5}$

According to the free radical theory of aging, scavenging free radicals can suppress the aging process. Free radicals can be neutralized by increasing the antioxidant intake. The dietary antioxidant can be acquired naturally from plants. ${ }^{2}$ Natural sources are safer due to their minimum side effects. Black soybean extract (BSE) can be used as an alternative aging therapy material due to its phenolic compound contents such as daidzein, which is an antioxidant. ${ }^{6}$ Isoflavone is a subgroup of flavonoids that have received the most attention as it contains bioactive compounds such as antioxidant, anti-aging, anti-cancer, and anti-inflammatory compounds. According to Neveu et al. ${ }^{7}$ black soybean also contains active compounds such as genistein, 6"-0-malonyldaidzin, genistin, gallic acid, 5-caffeoylquinic acid, daidzein, daidzin, ferulic acid, p-coumaric acid, and gentisic acid. In black soybean, $1.27 \mathrm{mg}$ of daidzein is contained in $100 \mathrm{~g}$ black soybean.

In this study, the antioxidant and free radical scavenging activities of BSE and daidzein were evaluated. The antioxidant activity was assessed to examine the ability of the two compounds in scavenging ${ }^{\circ} \mathrm{OH}$ and $\mathrm{NO} \cdot{ }^{\bullet} \mathrm{OH}$ assay in this study used the modified deoxyribose method while NO scavenging assay was performed using the sodium nitroprusside (SNP) method. ${ }^{8,9}$

\section{Methods}

This study was carried out in Aretha Medika Utama-Biomolecular and Biomedical Research
Center in Bandung, Indonesia, from September to November 2018. Black soybeans (Glycine $\max$ (L.) Merr.) were obtained from the Seed Source Management Unit ((Unit Pengelolaan Benih Sumber) Research Institute for Various Beans and Tubers, Malang, East Java. The bean was authenticated by the herbarium staff of the School of Life Science and Technology, Bandung Institute of Technology, Bandung, West Java, Indonesia. Dried black soybean (250 grams) were mashed and macerated using distilled ethanol 70\%. Every 24 hours, the ethanol was filtrated. The filtrate was then collected and condensed at $50^{\circ} \mathrm{C}$ using a rotary evaporator (Zhengzhou Well-known, RE-201D) to obtain BSE, which was then stored at $-20{ }^{\circ} \mathrm{C} .{ }^{4,5,10,11,12}$

The total phenol content in BSE was determined using Folin-Ciocalteu reagent (Merck, 1090010500). Fifteen microliters sample at a final concentration of $1000 \mu \mathrm{g} \mu \mathrm{g} /$ $\mathrm{mL}$ or Gallic acid (Sigma-Aldrich, 398225) at a final concentration of $50-1.56 \mu \mathrm{g} / \mathrm{mL}$ were introduced into a 96-well plate. Then, $75 \mu \mathrm{L}$ of Folin-Ciocalteu reagent (10\%). and $60 \mu \mathrm{L}$ of sodium carbonate (Merck, A897992745) $7.5 \%$ were added. The plate was incubated at $50^{\circ} \mathrm{C}$ for 10 mins. The absorbance value was measured using Multiskan ${ }^{\mathrm{TM}}$ GO Microplate Spectrophotometer (Thermo Scientific) at 760 $\mathrm{nm}$ wavelength. The total phenol value was presented as $\mu \mathrm{g}$ of Gallic Acid equivalent (GAE) in $1 \mathrm{mg}$ of the extract. ${ }^{4,5,13}$

Total flavonoid content in BSE was examined using the slightly modified aluminum chloride colorimetric method. ${ }^{14}$ Seventy-five microliters of sample or quercetin (Sigma-Aldrich, Q4951), at a final concentration of $1,000 \mu \mathrm{g} / \mathrm{mL}$, were mixed with $75 \mu \mathrm{L}$ of $2 \%$ Aluminum chloride (Sigma-Aldrich, 237051) solution then incubated at room temperature for $10 \mathrm{~min}$. The absorbance of the mixture was measured using Multiskan ${ }^{\mathrm{TM}}$ GO Microplate Spectrophotometer (Thermo Scientific) at $415 \mathrm{~nm}$ wavelength against a blank sample without aluminum chloride. Quercetin in various concentrations $(500 \mu \mathrm{g} / \mathrm{mL}-3.9 \mu \mathrm{g} / \mathrm{mL})$ was used as the standard. Total flavonoid content was expressed in $\mu \mathrm{g}$ of quercetin equivalents (QE) contained in 1 mg extract ${ }^{14}$.

- $\mathrm{OH}$ scavenging activities of the extract and daidzein (Chengdu BioPurify, Cat No. BP0445) were determined according to the method described by Halliwell et al. ${ }^{8}$ with slight modifications. The reaction mixture contained $30 \mu \mathrm{L}$ of different concentrations of sample, 10 $\mu \mathrm{L}$ of $\mathrm{FeCl}_{3}$-EDTA (Merck, 1.039430250;), $5 \mu \mathrm{L}$ of $20 \mathrm{mM} \mathrm{H}_{2} \mathrm{O}_{2}$ (Merck, 822287), $5 \mu \mathrm{L}$ of $1 \mathrm{mM}$ 
M Irwan, et al: Antioxidant Activities of Black Soybean Extract (Glycine max (L.) Merr.) and Daidzein as Hydroxyl and Nitric Oxide Scavengers

Table 1 Total Phenolic Content of BSE with Gallic Acid as Standard

\begin{tabular}{cccc}
\hline Sample & Linear Equation & $\mathbf{R}^{2}$ & Total Phenolic Content (Mg Gae/Mg Extract) \\
\hline BSE & $\mathrm{Y}=0.038 \mathrm{x}+0.192$ & 0.94 & $7.78 \pm 0.20$ \\
\hline
\end{tabular}

*Linear equations, coefficient of regression $\left(\mathrm{R}^{2}\right)$

Table 2 Total Flavonoid Content of BSE with Quercetin (QE) as Standard

\begin{tabular}{llcc}
\hline Sample & Linear Equation & $\mathbf{R}^{2}$ & Total Flavonoid Content $(\boldsymbol{\mu g} \mathbf{Q E} / \mathrm{mg}$ extract) \\
\hline BSE & $\mathrm{Y}=0.017 \mathrm{x}+0.036$ & 0.99 & $0.18 \pm 0.05$ \\
\hline
\end{tabular}

*Linear equations, coefficient of regression $\left(\mathrm{R}^{2}\right)$

L-Ascorbic acid (Sigma-Aldrich, K3125), $10 \mu \mathrm{L}$ of $28 \mathrm{Mm}$ Deoxyribose (Sigma-Aldrich, 121649), and $70 \mu \mathrm{L}$ phosphate buffer. The mixture was incubated at $37{ }^{\circ} \mathrm{C}$ for $30 \mathrm{~min}$ and then $25 \mu \mathrm{L}$ of 5\% TCA (Merck, 1008070250), and 1\% TBA(Sigma-Aldrich, T5500) were added to be further incubated at $80-90^{\circ} \mathrm{C}$ for $30 \mathrm{~min}$. The absorbance was measured at $532 \mathrm{~nm}$ wavelength using spectrophotometer. ${ }^{8}$

NO was generated by dissolving sodium nitroprusside (SNP) (Merck, 106541) in aqueous at a physiological $\mathrm{pH}$ of 7.2. NO reacts with oxygen to generate stable products (nitrate and nitrite) under aerobic conditions. Greiss reagent was used in NO assay. ${ }^{15}$ SNP $(10 \mathrm{mM})$ in phosphate buffer saline (Gibco, 1740576) was mixed with several concentrations (66.67-2.08 $\mu \mathrm{g} / \mathrm{mL}$ ) of BSE and daidzein. The mixture was then incubated for 2 hours at room temperature $\left(26^{\circ} \mathrm{C}\right)$. Next, Greiss reagent containing 1\% sulfanilamide (Merck, 1117999), 2\% $\mathrm{H}_{3} \mathrm{PO}_{4}$ (Merck, 100573), and 0.1\% N-(1-napththyl)ethylene diamine dihydrochloride (SigmaAldrich, 2224888) was added. The absorbance was measured at $546 \mathrm{~nm}$ wavelength. ${ }^{11}$

The antioxidant activity of BSE and daidzein in the experiment was determined as follows:

\section{\% scavenging activity=(Ac-As)/Ac $\times 100$}

Ac: negative control absorbance

As: sample absorbance

The assay was conducted in triplicate and results were expressed as a mean \pm standard deviation.
The significance of the results was determined using the one-way analysis of variance (one way ANOVA) with SPSS Statistic ver. 20.0 software. The probability values of $\mathrm{p}<0.05$ were considered as statistically significant based on Tukey's post hoc test.

\section{Results}

The total phenolic content of BSE was calculated using the Gallic acid equivalent. The total phenolic content in BSE was 7.78 $\pm 0.20 \mu \mathrm{g} \mathrm{GAE} / \mathrm{g}$ (Table 1).

The total flavonoid of BSE is listed in Table 2. Total flavonoid of BSE was $0.18 \pm 0.05 \mu \mathrm{gQE} /$ mg. Antioxidant activities of BSE and daidzein were evaluated using different methods in both ROS and RNS. $\cdot \mathrm{OH}$ scavenging assay was conducted as the representative of ROS and NO scavenging assay was used as the representative of RNS. These methods were applied to evaluate the antioxidant effects of BSE and daidzein as a scavenger for the two types of free radicals.

$\cdot \mathrm{OH}$ was generated in vitro using Fenton reaction for evaluating the BSE and daidzein free radical scavenging activities. The percentage of -OH scavenging activity of BSE and daidzein can be seen in Figure 1.

$\cdot \mathrm{OH}$ scavenging activity of BSE was concentration-dependent, where a higher concentration increases the scavenging activity. At the highest concentration $(26.67 \mu \mathrm{g} / \mathrm{mL})$,

Table 3 IC $_{50}$ value $\cdot \mathrm{OH}$ scavenging activity of BSE and daidzein

\begin{tabular}{lccc}
\hline \multicolumn{1}{c}{ Samples } & Equation & $\mathbf{R}^{2}$ & IC $_{50}(\boldsymbol{\mu g} / \mathbf{m L})$ \\
\hline BSE & $\mathrm{Y}=0.5942 \mathrm{x}+7.2351$ & 0.99 & 71.07 \\
Daidzein & $\mathrm{Y}=1.3625 \mathrm{x}+16.388$ & 0.97 & 24.57 \\
\hline
\end{tabular}

*Linear equations, coefficient of regression $\left(\mathrm{R}^{2}\right)$, and $\mathrm{IC}_{50}$ of each sample was calculated 
M Irwan, et al: Antioxidant Activities of Black Soybean Extract (Glycine max (L.) Merr.) and Daidzein as Hydroxyl and Nitric Oxide Scavengers

Table $4 \mathrm{IC}_{50}$ value NO Scavenging Activity of BSE and Daidzein

\begin{tabular}{lccc}
\multicolumn{1}{c}{ Sample } & Equation & $\mathbf{R}^{2}$ & IC $_{50}(\boldsymbol{\mu g} / \mathbf{m L})$ \\
\hline BSE & $\mathrm{Y}=0.4821 \mathrm{x}+15.488$ & 0.95 & 71.60 \\
Daidzein & $\mathrm{Y}=0.7401 \mathrm{x}+23.627$ & 0.96 & 35.68 \\
\hline
\end{tabular}

*Linear equations, coefficient of regression $\left(\mathrm{R}^{2}\right)$, and $\mathrm{IC}_{50}$ of each sample was calculated

daidzein had a higher $\cdot \mathrm{OH}$ activity compared to BSE $\quad(51.56 \pm 1.81 \%$ and $22.99 \pm 1.47 \%$, respectively) (Figure 1).

The median inhibitory concentration $\left(\mathrm{IC}_{50}\right)$ value ofBSEanddaidzeininhibitory concentration $\left(\mathrm{IC}_{50}\right)$ towards ${ }^{\circ} \mathrm{OH}$ scavenging activity can be seen in Table 3. IC $_{50}$ value for daidzein was lower $(24.57 \mu \mathrm{g} / \mathrm{mL})$ when compared to BSE $(71.07$ $\mu \mathrm{g} / \mathrm{mL}$ ) (Table 3). Results indicated BSE has a lower ${ }^{\circ} \mathrm{OH}$ scavenging activity.

Furthermore, NO was generated in vitro using sodium nitroprusside (SNP) for evaluating the free radical scavenging activities of BSE and Daidzein. The percentage of NO scavenging activities of BSE and Daidzein is depicted in Figure 2.

Based on the result, NO scavenging activity was concentration-dependent, where a higher concentration increased the NO scavenging activity. At the highest concentration $(66.67 \mu \mathrm{g} /$ $\mathrm{mL}$ ), daidzein had a higher scavenging activity when compared to BSE $(69.83 \pm 0.66 \%$ and $45.37 \pm 1.00 \%$, respectively) (Figure 2).

$\mathrm{IC}_{50}$ value of samples towards NO scavenging activities is listed in Table 4. Daidzein had the lowest $\mathrm{IC}_{50}$ value $(35.68 \mu \mathrm{g} / \mathrm{mL})$ when compared to BSE $(71.60 \mu \mathrm{g} / \mathrm{mL})$ (Table 3). These results suggested that BSE had a lower NO scavenging activity compared to daidzein.

The significance of NO scavenging percentage of BSE and daidzein is depicted in Figure 2.

According to the free radical theory of aging, $\cdot \mathrm{OH}$ and $\mathrm{NO}$ contribute to aging-related protein degradation such as collagen, hyaluronic, and elastin. ${ }^{4}$ Moreover, NO radical stimulates the degradation of collagen that constitutes $70-80 \%$

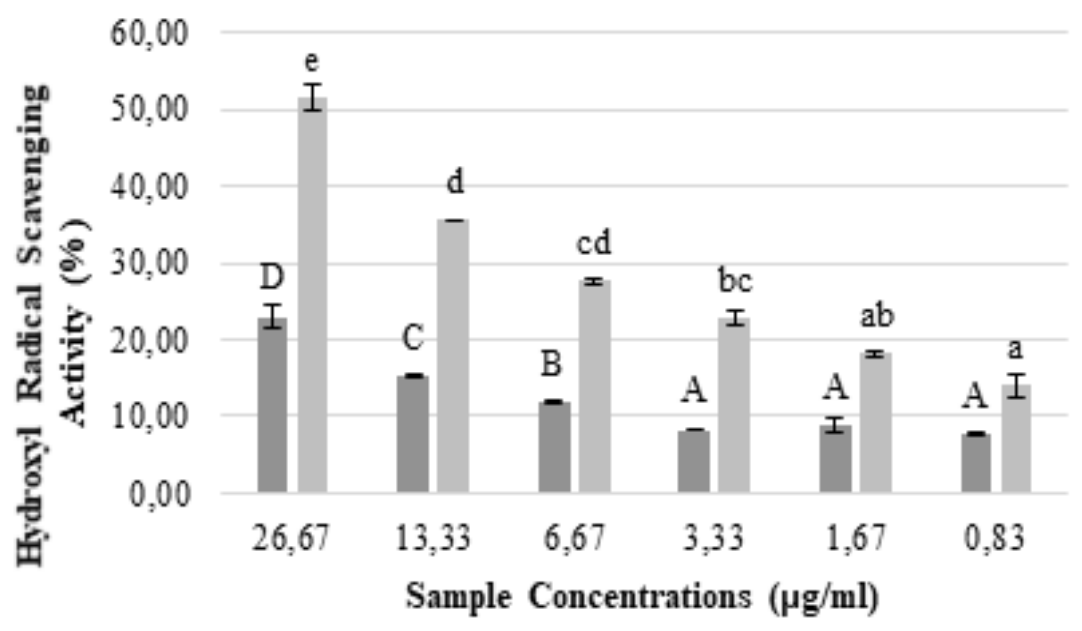

$\square$ BSE Daidzein

Figure $1 \cdot 0 \mathrm{H}$ scavenging activities of BSE and daidzein. BSE and daidzein were diluted in $10 \%$ DMSO to reach a final concentration of $26.67 ; 13.33 ; 6.67 ; 3.33 ; 1.67 ;$ and $0.83(\mu \mathrm{g} / \mathrm{mL})$. Data were presented as mean \pm standard deviation. Capital letter represents significant differences between concentrations of BSE and small letters represent significant differences between concentrations of daidzein at $\mathrm{p}<0.05$ (Tukey HSD post hoc test) 


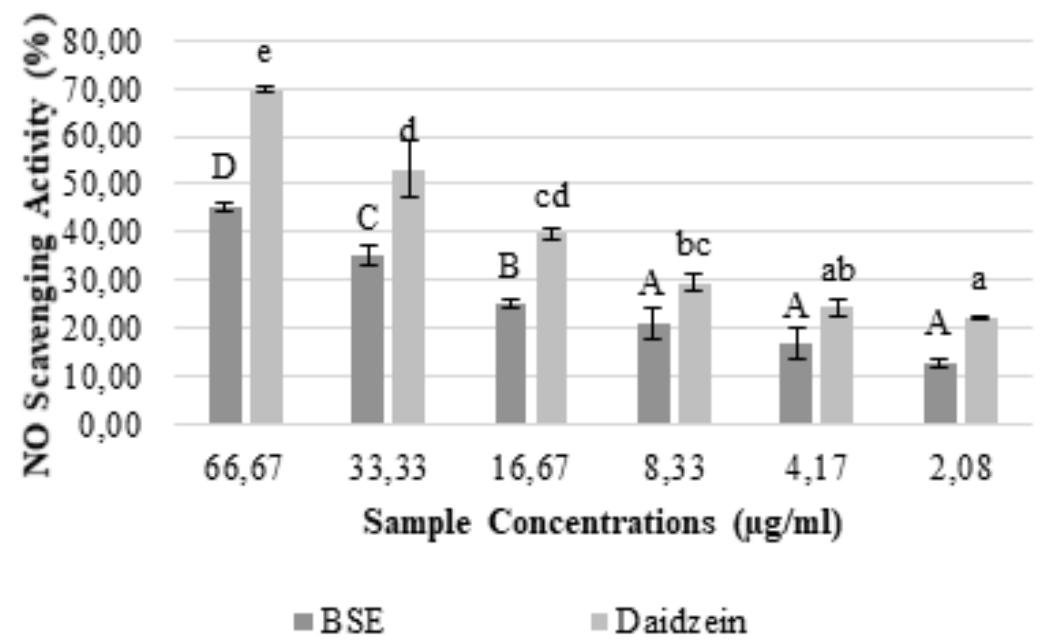

Figure 2 NO scavenging activity of BSE and daidzein. BSE and daidzein were diluted in DMSO 10\% to reach the final concentration of $66.67 ; 33.33 ; 16.67 ; 8.33 ; 4.17 ; 2.08(\mu \mathrm{g} / \mathrm{mL})$. Data were presented as mean \pm standard deviation. Capital letter represents significant differences between concentrations of BSE and small letters represent significant differences between concentrations of daidzein at $\mathbf{p}<0.05$ (Tukey HSD post hoc test)

of the total skin weight. Collagen loss causes skin to lose fullness and creates wrinkles.

\section{Discussion}

Total phenol and flavonoid assay was intended to determine phenol and flavonoid content contained in BSE. Prahastuti et al. ${ }^{10}$ reported the total phenol of $5.60 \pm 0.18 \mathrm{GAE} \mu \mathrm{g} / \mathrm{mg}$ BSE and $2.03 \pm 0.12 \mathrm{QE} \mu \mathrm{g} / \mathrm{mg}$ BSE for total flavonoid in their extract. Meanwhile, Dajanta et al. ${ }^{17}$ reported 8.54 $\pm 0.11 \mathrm{mg}$ GAE$/ \mathrm{g}$ BSE and 2.06 $\pm 0.00 \mathrm{mg}$ $\mathrm{CE} / \mathrm{g}$ BSE for total phenolic and total flavonoid of cooked non-fermented black soybean extract. This study presents a higher total phenol but lower total flavonoid than those presented by Prahastuti et al. ${ }^{10}$ and had lower total phenol and flavonoid values than those presented by Dajanta et al. ${ }^{17}$

In the present study, BSE and daidzein showed an antioxidant activity in a concentrationdependent manner. This is seen in Figures 1 and 2 , showing that the higher concentration results in a higher scavenging activity in the sample. Daidzein has a higher scavenging activity for both ${ }^{\circ} \mathrm{OH}$ and $\mathrm{NO}$ radicals than BSE. It is apparent in Tables 1 and 2 that daidzein has lower $\mathrm{IC}_{50}$ than BSE. A previous study conducted by Zhou et al. ${ }^{16}$ showed a value of around $6.2 \mu \mathrm{g}$ GAE/ mg. According to Widowati et al., ${ }^{18}$ the lower $\mathrm{IC}_{50}$ value is, the better its ability to scavenge the free radicals. Although the BSE has a higher $\mathrm{IC}_{50}$ value than daidzein, it still shows a strong antioxidant activity. Samples present various powerful antioxidant activities such as a strong antioxidant activity ( $\mathrm{IC}_{50}$ value $50-100 \mu \mathrm{g} / \mathrm{mL}$ ), moderate antioxidant activity $\left(\mathrm{IC}_{50}\right.$ value $100-$ $150 \mu \mathrm{g} / \mathrm{mL}$ ), dan weak antioxidant activity ( IC $_{50}$ value $151-200 \mu \mathrm{g} / \mathrm{mL})^{5}$

The low antioxidant activity of Glycine $\max$ (L.) Merr. might be related to the small number of phytochemicals flavonoids and polyphenols. The $\cdot \mathrm{OH}$ group molecule is very important for ${ }^{\circ} \mathrm{OH}$ radical scavenging. ${ }^{19}$ Based on Tiwari \& Mishra, ${ }^{20}$ daidzein is able to scavenge ${ }^{\circ} \mathrm{OH}$ through several mechanisms such as single electron transfer (SET), hydrogen atom transfer (HAT), and sequential proton-loss electron transfer (SPLET). The SPLET mechanisms are predicted to be the most effective way of daidzein to neutralize the $\cdot \mathrm{OH}$.

The common two-step sequential proton-loss electron-transfer (SPLET) reaction equation is 
presented below:

$$
\begin{aligned}
& \mathrm{A}(\mathrm{A}-\mathrm{H})^{-}+\mathrm{H}^{+} \rightarrow \\
& (\mathrm{A}-\mathrm{H})^{-}+\mathrm{R} \stackrel{\Delta \mathrm{G}^{b}}{\stackrel{\text { SPEET }}{\rightarrow}}(\mathrm{A}-\mathrm{H})+\mathrm{R}^{-}
\end{aligned}
$$

In the equation above, $\mathrm{A}$ is the antioxidant, $(\mathrm{A}-\mathrm{H})^{-}$is the deprotonated antioxidant anion, $\mathrm{R}^{-}$is the free radical, $(\mathrm{A}-\mathrm{H})$ is the free radical after the loss of one hydrogen and $\mathrm{R}^{-}$is the anion of the free radical that is less reactive than the corresponding free radical. ${ }^{20}$

The antioxidant assay of BSE and daidzein revealed that daidzein possesses a higher antioxidant activity than BSE (Table 1 and 2). In addition, the differences in the antioxidant activity values between assays indicate that each assay determines a different aspect in measuring the antioxidant capacity, distinct radicals, and mechanisms of reaction that occur. ${ }^{2}$ BSE exhibits the lowest activity both in ${ }^{\circ} \mathrm{OH}$ assay and NO assay, suggesting that daidzein has the higher antioxidant potential than BSE due to a presence of ${ }^{\bullet} \mathrm{OH}$ groups. In summary, Daidzein has higher an antioxidant activity through $\cdot \mathrm{OH}$ and $\mathrm{NO}$ scavenging compared to Glycine max (L.) Merr. extract. Hence, daidzein has more potentials for anti-aging according to the free-radical theory of aging.

\section{Acknowledgment}

This study was funded by Universitas Prima Indonesia. Aretha Medika Utama Biomolecular and Biomedical Research Center, Bandung, Indonesia supported this study with laboratory facilities and research methodology. We also would like to thank Hanna Sari Widya Kusuma, Rr. Anisa Siwianti Handayani, Dewani Tediana Yusepany, Dwi Surya Artie, Ika Adhani Sholihah, Kamila Yashfa Gunawan, Seila Arumwardana, Alya Mardhotillah Azizah, Enden Dea Nataya, and Jenifer Kiem Aviani for their valuable assistance.

\section{References}

1. Soltes L, Kogan G. Hyaluronan-an information rich messenger reporting on the physiological and pathophysiological status of synovial joints. Polymers Research Journal. 2010;8(1):49-73.

2. Peng $\mathrm{C}$, Wang $\mathrm{X}$, Chen J, Jiao R, Wang $\mathrm{L}$, Li YM, et al. Biology of ageing and role of dietary antioxidants. Biology of ageing and role of dietary antioxidants. Biomed Res Int. 2014;2014:831841.

3. Phaniendra A, Jestadi DB, Periyasamy L. Free radicals: properties, sources, targets, and their implication in various diseases. Indian J Clin Biochem. 2015;30(1):11-26.

4. Widowati W, Fauziah N, Herdiman H, Afni M, Afifah E, Kusuma HSW, et al. Antioxidant and anti aging assays of Oryza sativa extracts, vanilin, and coumaric acid. J Nat Remed. 2016;16(3):88-99.

5. Widowati W, Rani AP, Hamzah RA, Arumwardana S, Afifah E, Kusuma HSW, et al. Antioxidant and antiaging assays of Hibiscus sabdariffa extract and its compounds. Nat Prod Sci. 2017;23(3):192-200.

6. Asan T, Lister IN, Fachrial E, Amalia A, Widowati W, Samin B, et al. Potency of black soybean (glycine max (l.) merr) extract and daidzein as antioxidant and antihyaluronidase. Trad Med J. 2019;24(1): 52-8.

7. Neveu V, Perez-Jimenez J, Vos F, Crespy V, du Chaffaut L, Mennen L et al. PhenolExplorer: an online comprehensive database on polyphenol contents in foods. Database (Oxford). 2010;2010:bap024.

8. Halliwell B, Gutteridge JM, Aruoma OI. The deoxyribose method: a simple "test-tube" assay for determination of rate constants for reactions of hydroxyl radicals. Anal Biochem. 1987;165(1):215-9.

9. Utami S, Sachrowardi QR, Damayanti NA, Wardhana A, Syarif I, Nafik S, et al. Antioxidants, anticollagenase and antielastase potentials of ethanolic extract of ripe sesoot (Garcinia picrorrhiza Miq.) fruit as antiaging. J Herbmed Pharmacol. 2018;7(2):88-93.

10. Prahastuti S, Hidayat M, Hasianna ST, Widowati W, Amalia A, Yusepany DT, et al. Antioxidant potential ethanolic extract of Glycine max (1.) Merr. Var. Detam and daidzein. Int J Phys Conf Ser. 2019;1374(1): $1-12$.

11. Widowati W, Wargasetia TL, Afifah E, Mozef T, Kusuma HSW, Nufus H, et al. Antioxidant and antidiabetic potential of Curcuma longa and its compounds. Asian J Agri Biol. 2018;6(2):149-61.

12. Widowati W, Janeva WB, Nadya S, Amalia A, Arumwardana S, Kusuma HSW, et al. Antioxidant and antiaging activities of Jasminum sambacextract, and its compounds. J Rep Pharm Sci. 2018;7(3):270-85.

13. Widowati W, Herlina T, Ratnawati $\mathrm{H}$, 
Constantia G, Deva IDGS, Maesaroh M. Antioxidant potential of black, green and oolong tea methanol extract. Biolog Med Nat Product Chem. 2015;4(2):35-9.

14. Pothihirat W, Chomnawang MT, Supabphol $\mathrm{R}$, Gritsanapan W. Comparison of bioactive compounds content, free radical scavenging and anti-acne inducing bacteria activities of extracts from the mangosteen fruit rind at two stages of maturity. Fitoterapia. 2009;80(1):442-7.

15. Amudha M, Rani S. Evaluation of in vitro antioxidant potential of Cordia retusa. Indian J Pharm Sci. 2016;78(1):80-6.

16. Zhou R, Cai W, Xu B. Phytochemical profiles of black and yellow soybeans as affected by roasting. Int J Food Prop. 2017;20(12):317990.
17. Dajanta K, Janpum P, Leksing W. Antioxidant capacities, total phenolics and flavonoids in black and yellow soybeans fermented by Bacillus subtilis: A comparative study of Thai fermented soybeans (thua nao). Int Food Res J. 2013;20(6):3125-32.

18. Widowati W, Wijaya L, Wargasetia TL, Bachtiar I, Yellianty Y, Laksmitawati DR. Antioxidant, anticancer, and apoptosisinducing effects of Piper extracts in HeLa cells. J Exp Integr Med. 2013;3(3):225-30.

19. Treml J, Smejkal K. Flavonoids as potent scavengers of hydroxyl radicals. Compr Rev Food Sci Food Saf. 2016;15(4):720-38.

20. Tiwari MK, Mishra PC. Scavenging of hydroxyl, methoxy, and nitrogen dioxide free radicals by some methylated isoflavones. J Mol. 2018;24(10):287. 